\title{
A Study on the Potential of Processed Banana Agroindustry: An Effort to Strengthen Food Security
}

\author{
Nuning Setyowati \\ Dept.Agribusiness, Agricultural Faculty \\ Universitas Sebelas Maret \\ Solo, Indonesia \\ noenk_setyo@yahoo.com \\ Suprapti Supardi \\ Dept.Agribusiness, Agricultural Faculty \\ Universitas Sebelas Maret \\ Solo, Indonesia \\ nuning_s@staff.uns.ac.id
}

\author{
Agustono \\ Dept.Agribusiness, Agricultural Faculty \\ Universitas Sebelas Maret \\ Solo, Indonesia \\ agustono0108@gmail.com \\ Wiwit Rahayu \\ Dept.Agribusiness, Agricultural Faculty \\ Universitas Sebelas Maret \\ Solo, Indonesia \\ wiwit_uns@yahoo.com
}

\begin{abstract}
Bojonegoro is a region in East Java Province affected with annual flood. Food security, particularly in flood-vulnerable areas, is urgent to improve. Developing Agroindustry is a solution to improve the performance of agricultural sector to achieve food security for local communities. Banana is a superior agricultural commodity in Bojonegoro regency. This study aimed to map the potential of processed-banana agroindustry and to analyze the feasibility of processed-bananas agroindustry. This study applied descriptive method with ECM and Borda analysis. The results showed that processed-banana agroindustry in Bojonegoro by its superior commodity ranking included ledre, banana chips, banana gethuk and banana hump chips. Considering the results of feasibility analysis, it could be concluded that that ledre as the first-ranking commodity is profitable to develop in the future.
\end{abstract}

Keywords: Borda, ECM, Feasibility, Processed Banana

\section{INTRODUCTION}

The objective of regional development, among others, is to improve economic development. Economic development is a progress in which local government and community manage the available resources and establish partnership between local government and private sectors in creating jobs and stimulating economic activities in the region (Arsyad, 2010). Agriculture can be considered as the mainstay of economy and it is fundamental to a nation's socio-economic development because it is a major element and factor in national development (Olaoye, 2014). Agrifood industry plays a fundamental role in creating income and employment opportunity in developing countries (UNDP, 2012). Furthermore, agrifood industry plays a substantial role to strengthen food security. Food security has been defined in terms of food availability and its accessibility to people (Olaoye, 2013). Food security refers to the situation when all people have physical, social and economic access to sufficient, safe and nutritious food meeting their dietary needs and food preferences for an active and healthy life at any given time" (FAO, 2010).

Natural disasters can affect significantly economic and food security, especially in poor households. One of the natural disasters is flood. Flood can create devastating impacts on people's food security and livelihood (Riptanti et al, 2016).

Bojonegoro Regency is a flood-vulnerable area with annual flooding potential. The effect of flood also becomes a threat against agricultural sector. Flood affected 5,011 hectares of paddy fields and 1,157 hectares of fields (PBP Satlak Bojonegoro, 2009). This condition in long term will affect the food security in Bojonegoro, because flood results in the decreased food production and then lead to low food availability.

The annual flood potential requires Bojonegoro to strive for strengthening its food security when the flood happens. Food security cannot depend on farm alone. It also needs an attempt to increase the added value of agricultural commodities. Agroindustry is a solution to increase the added value of commodities and to increase the people's income or food purchasing power.

Agustono, et al (2010) said that the strategy to identify and develop superior agricultural commodities in Bojonegoro successfully identified some other agricultural commodities superior to banana: rice, soybeans and cattle. Banana was selected as the object of research because banana is very potential in Bojonegoro. This commodity is flood-resistant and grows very well along Bengawan Solo riverbanks throughout Bojonegoro areas. Two of the strategies that can be undertaken to develop banana commodity, according to Agustono et al (2010), are to diversify processed products made from bananas and to improve banana-based agroindustry.

This study aimed to identify the potential of processed banana agroindustry at sub-district and district levels in Bojonegoro. Furthermore, this study aimed to analyze the feasibility of the first-rank processed banana agroindustry in Bojonegoro. The development of banana-based agroindustry and the diversification of product made from bananas are expected to increase income and purchasing power of the communities, thereby strengthening economic access to food in order to ensure food availability. 


\section{METHODS}

\section{A. Fundamental Methods}

This research employed descriptive method. Descriptive research method was designed to obtain answers related to an individual's opinion, response or perception (Sulistyo, 2010). This research used survey technique and the sample was selected from one population using questionnaire as an instrument of collecting data (Singarimbun, 2006).

\section{B. Research Location}

The location of research was selected purposively due to some reasons (Singarimbun, 2006). The research location selected was Bojonegoro for the following reasons: (1) agricultural sector provided the second largest contribution to Bojonegoro regency's economy, $14.43 \%$ in 2017; (2) Bojonegoro is a flood -vulnerable area requiring an attempt to support food security based on local potency; and (3) banana is a commodity with largest production $(1,228,180$ tons in 2017) among other fruit commodity groups, so that it is highly potential to develop its agroindustry.

\section{Types and Sources of Data}

The types of data used in this research were primary and secondary data. Primary data were used to map the potential of banana and banana agroindustry. The data on banana agroindustry included: number of banana agroindustry, raw material availability, market scope, and its contribution to economy, and government policy related to the development of banana agroindustry.

Primary data were collected using questionnaires and in-depth interviews (Ruslan, 2003). To obtain data with various characteristics, a structured questionnaire adapted from Bank Indonesia was employed. In addition, this research also used Focus Group Discussion as data collection instrument.

Secondary data used included Gross Regional Domestic Product (GRDP) of Bojonegoro ADHK 2000 2005-2008, Bojonegoro in Figures 2009, data about potential banana commodity from the Department of Agriculture, Agroindustry Potential Data from the Department of Industry \& Trade, and Monograph of Bojonegoro. Secondary data were collected by recording or copying documents.

\section{Sampling Method}

The mapping of banana agroindustry was carried out in all (27) sub districts in Bojonegoro regency: Margomulyo, Ngraho, Purwosari, Padangan, Kasiman, Malo, Kalitidu, Trucuk, Bojonegoro, Dander, Balen, Kanor, Cotton, Sumberejo, Baureno, Tambakrejo, Ngambon, Sekar, Bubulan, Gondang, Temayang, Sugihwaras, Kedungadem, Kepohbaru, Sukosewu, Ngasem and Kedewan. The respondents interviewed on stage to map the potential of banana agroindustry consisted of three respondents in each district: farmers, statisticians and economists.
To study the economic feasibility of banana processed agroindustry, the samples taken were owners of banana processed agroindustry consisting of 30 respondents. Sample was selected proportionally based on the results of banana processed agroindustry distribution mapping using the following formula:

$$
\mathrm{Ni}=\frac{N k}{N} \cdot \mathrm{n}
$$

In which:

$\mathrm{Ni}=$ number of processed banana agroindustry performers in sub district $\mathrm{X}$ becoming the research samples

$\mathrm{Nk}=$ total number of processed banana agroindustry performers in the sub district

$\mathrm{N}=$ total number of processed banana agroindustry performers in all sub districts

$\mathrm{n}=$ total number of agroindustry actor samples (30)

E. Data Analysis

1) Mapping of processed-banana agroindustry potential at sub district level in Bojonegoro Regency

Ranking of bananas agroindustry at sub district level was determined using four criteria adapted from The Bank of Indonesia (2010):

- Number of business units / households owning agroindustry

- Market, with the criteria of agroindustry product marketing coverage

- The availability of agroindustry raw materials/tools

- Agroindustry's contribution to local economy

Analysis on the establishment of agroindustry was carried out using the ECM (exponential comparison method). The method was used to determine the alternative priority order decision with multiple criteria (Marimin, 2004).

The selection of each alternative processed-banana agroindustry was set based on research or opinion sources obtained through interviewing the respondents (peasant or farmer, statistician, and economist). The analysis formulation of exponential comparison method was adapted from Marimin (2004) as follows:

$$
\text { Total value }(\mathrm{TNi})=\sum_{j=1}^{m}(R K i j){ }_{\mathrm{TKKj}}
$$

In which:

$$
\begin{aligned}
\mathrm{TNi}_{\mathrm{ij}}= & \text { the } i \text {-th total alternative value for }(\mathrm{i}) \\
\mathrm{RK}_{\mathrm{ij}} & \begin{array}{l}
\text { Relative degree of importance for the } j \text {-th } \\
\text { criteria of decision option }
\end{array} \\
\mathrm{TKK}_{\mathrm{ij}}= & \begin{array}{l}
\text { Degree of importance for the } j \text {-th decision } \\
\text { criteria, } \mathrm{TKK}>0 ; \text { rounded }
\end{array} \\
\mathrm{i} & =1,2,3 \ldots \mathrm{n} ; \mathrm{n}=\text { number of decision options } \\
\mathrm{m} & =
\end{aligned}
$$




\section{2) Identification of bananas-processed Agroindustry in Bojonegoro Regency}

Considering the result of the identification of processed-banana agroindustry in all sub districts with exponential comparison method, the selection of 10 major processed-banana agroindustry at Regency level was conducted using Borda method.

Borda Method is used to determine the rank (Marimin, 2004). Based on calculations using Borda Method, the top ten processed-banana agro-industries in the regency were analysed, so that the position or potential of bananaprocessed agroindustry in Bojonegoro can be determined. The formula of calculation using Borda Method was elaborated as follows:

Borda $X$ Value $=\Sigma($ ECM $X *$ number of
alternative agroindustry
ranks $)$

Where:

$\begin{array}{ll}\mathrm{X} & =\text { Agroindustry X } \\ \mathrm{ECM} & =\text { Exponential Comparison Method }\end{array}$

(number of alternative agroindustry ranks in each sub districts)

The output of agroindustry mapping includes: distribution of processed banana agroindustry, component costs and production cost, price, financing/ capital, financial management, human resources, technology, production, marketing and government policies.

a. Total cost and revenue

Total cost (TC) is the sum of fixed cost (TFC) and variable cost (TVC). Mathematically it is formulated as follows:

$\mathrm{TC}=\mathrm{TFC}+\mathrm{TVC}$

Where:

$\mathrm{TC}=$ Total cost (IDR)

$\mathrm{TFC}=$ Fixed costs (IDR)

$\mathrm{TVC}=$ Variable costs (IDR)

b. Revenue of bananas-processed agroindustry in Bojonegoro is formulated mathematically as follows:

$\mathrm{PR}=\mathrm{P} \times \mathrm{Q}$

Where:

PR = Revenue of processed-banana agroindustry (IDR)

$\mathrm{P} \quad=$ Price of product (IDR)

$\mathrm{Q}=$ Total production

c. Income is revenue minus total cost.

The calculation of income is mathematically formulated as follows:

$$
\pi \quad=\mathrm{PR}-\mathrm{TC}
$$

Where:

$\pi \quad=$ Income of processed-banana agroindustry (IDR)

$\mathrm{PR}=$ Revenue of processed-banana agroindustry IDR)
$\mathrm{TC}=$ total cost $\mathrm{f}$ of processed-banana agroindustry (IDR)

\section{RESULTS AND DISCUSSION}

\section{A. Description of Banana Potential}

Bojonegoro has several banana varieties such as Raja, Susu Subelero and Saba Pipit bananas. Commonly, farmers cultivate more than one variety of bananas. The most widely planted ones are Raja and pipit bananas. Both varieties are widely cultivated because of consumer demands. Some of the banana agro-industries in Bojonegoro are ledre (banana roll) and banana chips. Ledre is made from Raja banana while banana chips are made from saba pipit banana. Bananas are harvested 58 months after planting. Most farmers harvest their own banana but some farmers sell their banana on field, particularly those growing bananas in a wide area. The price of Raja banana is higher than that of saba pipit banana. The price of raja banana ranges between IDR $40,000.00$ and IDR 50,000.00. Meanwhile, the price of saba pipit banana ranges between IDR 20,000.00 and IDR $40,000.00$. Their revenue coming from banana sale ranges between IDR 410,000.00 and IDR 9,000,000.00 per year. Their revenue is dependent on production volume and banana price by its varieties.

In relation to the prospect of banana development, farmers assume that banana has a good prospect to develop. The factors taken as consideration in developing banana include high demand for banana, competitive price, government support, small capital requirement and technology support. Most farmers argue that banana has a good prospect to develop.

In developing bananas, farmers have preferences related to varieties, marketing, capital, and farming institution. The varieties preferred by farmers are raja and saba pipit bananas. Both varieties are preferred by the farmers for some reasons such as: high price, high demand, good durability, easiness to cultivate and compatibility to any seasons. The most favorite marketing channels used are direct selling in the market and through seller coming to the field during harvests. However, most farmers prefer to sell bananas directly in the market, assuming that they will be able to determine the price and to get higher price when selling bananas directly in the market. Meanwhile, some farmers prefer to sell bananas to middlemen, because this method is easier and they do not spend transportation cost. The most preferred capital is their own capital because it makes them more composed and having no debt. Whereas, the farming institution expected in banana development is the individual one because it can be implemented more easily and discretely without depending on others.

Banana has a good prospect to develop, but farmers also face several obstacles. The obstacles faced by farmers in Bojonegoro are in terms of cultivation and marketing. The obstacles related to cultivation are: unavailability of good seed, limited capital, traditional technology use, and government's inadequate attention. The obstacles related to marketing are price 
fluctuation and market location which is far from the farmers' houses.

The development of banana commodity requires government's support in terms of education about good cultivation, banana processing to increase added value, capital and technology grants, and price control that ensures farmers' profit.

\section{B. Mapping of Processed-banana Agroindustry Potential.}

The mapping of processed-banana agroindustry potential in every sub district in Bojonegoro regency was prepared using ECM. Based on the result of ECM analysis, several types of processed banana agro-industries were identified existing in the sub districts of Bojonegoro. The distribution of processed-banana agroindustry potential is presented as follows:

Table 1. Potential of Processed Banana Agroindustry at sub district level in Bojonegoro Regency

\begin{tabular}{|c|c|c|c|c|c|}
\hline \multirow[b]{2}{*}{ No. } & \multirow[b]{2}{*}{$\begin{array}{l}\text { Name of Sub } \\
\text { Districts }\end{array}$} & \multicolumn{4}{|c|}{ Value of EPM } \\
\hline & & $\begin{array}{c}\text { Banana } \\
\text { chips }\end{array}$ & Ledre & $\begin{array}{c}\text { Bananas } \\
\text { Gethuk }\end{array}$ & $\begin{array}{c}\text { Banana's } \\
\text { hump } \\
\text { chips } \\
\end{array}$ \\
\hline 1 & Margomulyo & $11,937,264.01$ & & & \\
\hline 2 & Ngraho & & $11,937,264.01$ & & \\
\hline 3 & Padangan & $16,778,271.05$ & $16,778,271.05$ & & \\
\hline 4 & Kalitidu & $391,219.09$ & & & \\
\hline 5 & Purwosari & & $8,366,099.63$ & & \\
\hline 6 & Ngasem & $655,321.74$ & & & \\
\hline 7 & Ngambon & $8,365,051.90$ & & & \\
\hline 8 & Trucuk & $6,751.68$ & & & $2,583.83$ \\
\hline 9 & Tambakrejo & & $27,252,478.80$ & & \\
\hline 10 & Malo & & $3,903,163.50$ & & \\
\hline 11 & Kanor & & & & \\
\hline 12 & Baureno & & & & \\
\hline 13 & Kepuhbaru & & & & \\
\hline 14 & Cotton & & & & \\
\hline 15 & Dander & $5,765,608.96$ & & & \\
\hline 16 & Sumberrejo & & & & \\
\hline 17 & Kedungadem & $1,680,197.83$ & & & \\
\hline 18 & Sugihwaras & & & & \\
\hline 19 & Sukosewu & & & & \\
\hline 20 & Temayang & & & & \\
\hline 21 & Sekar & & & & \\
\hline 22 & Balen & $1,071.77$ & & & \\
\hline 23 & Bubulan & $2,655.48$ & & $25,343.63$ & \\
\hline 24 & Gondang & & & & \\
\hline 25 & Kasiman & & & & \\
\hline 26 & Kadewan & & & & \\
\hline 27 & Bojonegoro & $66,021.05$ & & & \\
\hline
\end{tabular}

Source: Primary Data Analysis

The result of ECM analysis shows that there are four processed banana products in Bojonegoro regency: ledre, banana crispy chips, banana gethuk (traditional banana cake) and banana hump (root) chips. Ledre spreads over five sub districts: Purwosari, Padangan, Malo, Tambakrejo and Ngraho sub districts. Banana chips agroindustry is located in Margomulyo, Padangan, Kalitidu, Ngambon, Ngasem, Trucuk, Dander, Kedungadem, Balen, Bubulan and Bojonegoro sub districts. From the table of distribution above, it can be seen that banana chips agroindustry is the most widely spread one in Bojonegoro. There is only one Banana gethuk agroindustry in Bojonegoro. Considering the abundant availability of raw materials, more attempts need to be taken to develop banana gethuk agroindustry in the future. In addition, a number of banana tuber chip agroindustry is located in Trucuk. It is a new innovation in this area which is developed by a group of women. Raw materials used for this agroindustry is unique as they come from the root or tuber of banana trees often discarded because it is considered as useless.

Having identified the processed-banana agroindustry in every sub district, further analysis was conducted to identify the ranking of processed-banana agroindustry in Bojonegoro regency using Borda analysis. The result of Borda analysis is presented as follows:

Table 2. Ranking of Processed- Bananas Agroindustry in Bojonegoro Regency

\begin{tabular}{clr}
\hline RATING & \multicolumn{1}{c}{ AGROINDUSTRY } & VALUE OF BORDA \\
\hline I & Ledre & $341,186,384.95$ \\
II & Banana chips & $228,244,517.28$ \\
III & Banana Gethuk & $1,126,718.15$ \\
IV & Banana's hump chips & $10,335.31$ \\
\hline
\end{tabular}

Source: Primary Data Analysis

Considering the result of Borda analysis, the rankings of processed-banana agroindustry in Bojonegoro regency are sequentially: ledre, banana chips, banana gethuk and banana bunch chips, respectively.

Ledre occupies the first rank on processed-banana agroindustry because ledre is a well-known processedbanana product from Bojonegoro. Although it is produced in 5 sub districts only, ledre has potentially abundant raw materials so that there is no problem related to the raw material availability. In addition, agroindustry can contribute to the income of local communities and government. In relation to marketing, there are many agents or shops that are ready to receive this product.

Banana chips agroindustry is on the second rank. This is supported by the many banana chip entrepreneurs spreading over 11 sub districts. Banana chip is chosen because of its easy production process. Just like ledre, banana chip faces no obstacle in term of raw materials. As a food product that is quite familiar to the local community, the marketing of banana chip is relatively easy, but the obstacle is related to the number of competitors, from both inside and outside Bojonegoro. The high number of banana agro-industries results in substantial contribution to the improvement of local communities' economy and government's income.

Banana gethuk agroindustry is on the third rank following ledre and banana chips. Unfortunately, banana Gethuk agroindustry has not been familiar yet. Viewed from its raw material availability and potential market, this 
agroindustry has a good prospect. However, because only very few local people know how to make banana gethuk, this agroindustry has not been developed optimally. Considering the slightly simple process of producing banana gethuk and the easy procedure, socialization and training for producing banana gethuk should be conducted to develop this type of agroindustry utilizing abundant banana availability.

Banana hump chips agroindustry is on the last rank in Bojonegoro regency. This product is relatively new. Considering the result of a survey, there is only a group of women in Trucuk producing this food. Based on the survey, this product needs to be improved in the term of product taste, appearance, and packaging.

\section{Economic Analysis on Ledre Production}

Ledre is processed-banana product being the icon of Bojonegoro Regency. The ingredients of ledre are Raja banana, cocoa, milk, cheese, strawberry, sugar, rice flour, and peanut oil. Ledre product is marketed both inside and outside Bojonegoro. Ledre has some variants: original, chocolate, milk, cheese, strawberry, etc. Furthermore, viewed from its size, it can be divided into long, medium and short categories. Ledre has shelf life of about 4 months. There are some reasons why SMEs choose ledre agroindustry.

Table 3. The reasons of why entrepreneurs choose ledre as a business in Bojonegoro

\begin{tabular}{clcc}
\hline No & \multicolumn{1}{c}{ Reason } & Entrepreneur & $(\%)$ \\
\hline 1 & Profitable & 15 & 50,0 \\
2 & $\begin{array}{l}\text { Hereditary business } \\
\text { To help the household }\end{array}$ & 9 & 29,9 \\
3 & $\begin{array}{l}\text { economy } \\
4\end{array}$ & 4 & 13,4 \\
& Do not have another job & 2 & 6,7 \\
& $\quad$ Total & 30 & 100,0 \\
\hline
\end{tabular}

Source: Primary Data Analysis

A half of respondents chose ledre agroindustry as their livelihood because this business is profitable. Meanwhile, another half of the respondents chose ledre agroindustry because it is a hereditary business and helps contribute to household economy, and that they have no other job opportunity. They carry out production everyday with their own capital. Ledre agroindustry is a profitable business. The table below shows an overview of economic potential of ledre agroindustry (attached).

Table 4. Monthly Economic Analysis on Ledre agroindustry

\begin{tabular}{clr}
\hline No. & \multicolumn{1}{c}{ Component } & Value \\
\hline 1 & Total revenue (IDR) & $2,561,433$ \\
2 & Total Cost (IDR) & $2,031,947$ \\
3 & Profit (IDR) & 529,487 \\
\hline
\end{tabular}

Source: Primary Data Analysis

Table 4 shows that ledre agroindustry is profitable, despite its small profitability compared with other banana- processed products such as banana chips or banana gethuk. Because ledre production takes less cost, more local people can engage in this business. Ledre agroindustry is feasible to develop economically and has a good prospect as it is supported by the availability of bananas as raw material, entrepreneur's skill and broad market. Thus, the development of ledre agroindustry is expected to strengthen food security. People can access food more easily because ledre has longer expiry period

\section{CONCLUSION}

Banana is potential to be processed into various food products. The ranking of processed banana products in Bojonegoro district are sequentially: ledre, banana chips, banana gethuk and banana hump chips, respectively. Ledre agro-industry is profitable and feasible to develop and it needs government's support in the form of technological innovation, market expansion and management reinforcement.

\section{ACKNOWLEDGMENT}

The authors would like to express their gratitude to the Ministry of Research, Technology and Higher Education, Bojonegoro government and SME's for the participation.

\section{REFERENCES}

[1] Agustono. "Analysis of Impact Use of Production Factor Against Rice Production In Model-Based Local Agricultural Development (MPPBL) And Benefits to the Community economy". Journal of SEPA Volume 6 No. 2 February 2010.

[2] Agustono, Setyowati, N, Rahayu, W, Barokah, U. "Agricultural Commodity Development Strategy Featured In Flood Prone Areas to Support Successful Autonomous Region In Bojonegoro (Klassen Typology Approach And QSPM (Quantitative Strategic Planning Matrix)". National Strategic Research. Not published. 2010

[3] ArmanuThoyib. "Relationship Leadership, Culture, Strategy, and Performance: Concept Approach". Journal Management and Entrepreneurship.Vol 7 No March 1, 2007.

[4] Arsyad L. "Development Economic". Yogyakarta: UPP STIM YKPN. 46. 2010

[5] Balitbangtan. "Investment Policy Direction and Prospects for Agricultural Commodities 17 Service Business Tools and Machinery Agriculture and Land Development Potential of Agriculture”. Agency for Agricultural Research and Development. Agriculture Department. Jakarta. 2008

[6] Asri, M. Fundamentals of Learning Sciences. BPFE. Yogyakarta. 1987

[7] BAPPEDA Bojonegoro, Strategic Planning and Regional Development of Fast Growing (Industrial Area) Paser. Http://bappeda.paserkab.go.id/files/IX\%20REKOMENDASI.pdf. 2007

[8] BPS Bojonegoro. "Bojonegoro Dalam Angka2013-2017". BPS Bojonegoro. Bojonegoro.2018

[9] Djarwanto, P. and S. Pangestu. "Statistik Induktif". Fourth Edition. BPFE UGM. Yogyakarta. 1994

[10] Fajarningsih, UR, Setyowati, N. "Agricultural Sector Development Strategy to Support the Economy In Boyolali Volume 1 No. 2 February 2005.

[11] FAO, Food and Agriculture Organization of the United Nations. "Challenges of agribusiness and agroindustry development." Available at: ftp://ftp.fao.org/docrep/fao/meeting/011/j9176e. pdf. Accessed on 9th Nov., 2010

[12] Karmadi. "Analysis Efficiency And Productivity Home Industry Ledre (Case Study In the village Padangan Padangan Sub district Bojonegoro)". Thesis University of Malang.Unpublished. 2003 
[13] Luthfiyanti, R. "Map Availability Raw Banana Bananas In Supporting Agroindustri In the district of Subang, West Java". Proceedings Seminar of the National Science and Technology-II in 2008. University of Lampung 17-18 November 2008 ISBN: 978979-1165-74-7 VII-129

[14] Marimin."Teknik dan Aplikasi Pengambilan keputusan Kriteria Majemuk". Gramedia Widiasarana Indonesia. Jakarta. 2004

[15] Monika Palatkova. . "The McKinsey 7-S-Model: an Implementation Tool of a Destination Marketing Strategy in the Czech Republic". Global Management Journal. Vol. 3, No. 1, 2/2011. ISSN 20802951

[16] Olaoye, O.A., O.A. Idowu and I.G. Lawrence."Certain roles of the Food Scientist in ameliorating food insecurity in developing Countries particularly Nigeria".Journal of Food and Agricultural Science. 2013.

[17] Olaoye. O.A."Potentials of the Agro Industry towards Achieving Food Security in Nigeria and Other Sub-Saharan African Countries". Journal of Food Security, 2014, Vol. 2, No. 1, 33-41

[18] Pearce II, JA, and RB Robinson. "Strategic Management: Formulation, Implementation, and Control". Seventh Edition. Malaysia: McGraw-Hill International Editions. 2000

[19] Indonesia Center of Agricultural Socio Economic and Policy. "Increase Value Added through Agroindustry. News Agricultural Research and Development". Volume 30, No. 4 of 2008. Bogor

[20] Rangkuti, F." SWOT Analysis Techniques Dissecting the Business Case. PT Gramedia Pustaka Utama. Jakarta. 2001

[21] Riptanti, E.W ,Supardi, S and Qonita, A. "Sustainable Food Security on Farmer Households in Flood Prone Areas". International Journal of Applied Environmental Sciences ISSN 0973-6077 Volume 11, Number 6,2016., pp. 1435-1450

[22] Ruslan, R. "Research Methods Public Relations and Communications". PT. King Grafindo Persada. Jakarta.2003

[23] Satlak PBP Bojonegoro, 2009. "Peta Banjir Bojonegoro".

[24] Setyowati, N. "Development Strategy Of Paddy Commodity To Enhancing Food Security In Floods Gristle Regions In Bojonegoro".Proceedings of the International "Food Safety Food Security". Yogyakarta 1 to 4 December, 2010.

[25] Singarimbun M and Sofian E. “ Penelitian Survei”. LP3ES. Jakarta: 2006

[26]

Sukartawi."Characteristics

Agroindustri”. Accessed through www Agribisnis.com dated March 23 th 2011.

[27] Sulistyo B. "Metodologi Penelitian". Jakarta: Penaku. 2010

[28]Tarin, H. "Added Value through Banana Agroindustry Development

Lumajang". Http://pse.litbang.deptan.go.id/ind/pdffiles/ Semnas4Des07. 2007. 